\title{
Sedentary Screen Time and Gross Motor Skills of Indonesian Preschoolers in Urban Areas
}

\author{
Nurrul Riyad Fadhli \\ Universitas Negeri Malang \\ Malang, Indonesia \\ nurrul.riyad.fik@um.ac.id
}

\author{
Elok Ludyana \\ Universitas Negeri Malang \\ Malang, Indonesia \\ elokludyana20@gmail.com
}

\author{
Dona Sandy Yudasmara \\ Universitas Negeri Malang \\ Malang, Indonesia \\ dona.sandy.fik@um.ac.id
}

\author{
Taufik \\ Universitas Negeri Malang \\ Malang, Indonesia \\ taufik.fik@um.ac.id
}

\begin{abstract}
This study was to identify the duration of sedentary screen time (SST) and gross motor skills (GMS) of Indonesian preschoolers in the urban area. This study used an IPAQ questionnaire and Test of Gross Development (TGMD) to collect data. Preschoolers who live in urban area are involved in this study. This study indicated that most of children in the urban area tends to have a duration of sedentary screen time more than 1 hour per day (95\% \pm CI: 45.96-54.04). GMS level in non-locomotor aspects showed descriptive statistical identification results (20.19-62), and object control (25.48-66.48) with $(95 \% \pm$ CI: $45.96-54.04)$. It can be concluded that the level of GMS of Indonesian preschoolers that live in urban area is strongly influenced by sedentary screen time.
\end{abstract}

Keywords-- Sedentary Screen Time, Gross Motor Skills, Preschool-age Children.

\section{INTRODUCTION}

Technology is the result of human innovation from the demands of the era of globalization. The latest innovations in technology today are gadgets. Almost all circles of society have taken advantage of the existence of gadgets, both children, teenagers, adults, and parents. According to data from the Ministry of Communication and Information (KOMINFO) in 2018, Indonesia is the 4th largest gadget user country in the world after India, China, and the United States. The number of gadget users in Indonesia is more than 100 million people. Children today are born in the era of digital technology, gadgets and computers such as tablets and smartphones have become their daily friends (Mashrah, 2018). Based on research published by

\author{
Eldiene Zaura I'tamada \\ Universitas Negeri Malang \\ Malang, Indonesia \\ itamada012@gmail.com
}

uswitch.com, shows that more than $25 \%$ of children around the world have a gadget before they turn 8 years old. One in three children starts using gadgets when they are 3 years old and one in ten children enjoy gadgets at a younger age of 2 years (Dwi Murdaningsih \& Mansyur Faqih, 2014). The advantage of having a gadget is that it can make it easier for children to get access to information and technology media. Unfortunately, this shapes the character of children who become lazy to move and do activities. They will prefer to sit and enjoy the world that is in the gadget. These conditions will affect the development of children, both in terms of physical, motor, psychological and social children.

The World Health Organization (WHO) reports that $5-25 \%$ of preschool-aged children suffer from developmental disorders. It is recorded that 8 to $9 \%$ of preschool-aged children experience problems with the psychomotor development of children such as the level of gross motor skills. Various stimulations can affect children's development, including gadgets. The existence of gadgets makes children have poor motor skills (Aldimasi et al., 2018). Parents should consider how much time is allowed for preschool-aged children to play with gadgets because the total duration of gadget use is feared to increase the rate of gadget addiction and affect children's physical and motor development. Addiction to gadgets can increase the prevalence of the risk of attention deficit disorder and hyperactivity. Children who spend most of their time playing just by playing with gadgets, cause them to become children who tend to be lazy to move and move. Children like this will later grow and develop into obese or 
overweight children because they lack physical activity and are busy spending samba food and playing gadgets. If this happens, it will hinder the child's motor development.

In essence, children who use gadgets with normal frequency will spend some of their time with motor activities such as doing gross motor movements such as walking, jumping, tiptoeing and also running (Elfiadi, 2018). The duration of using gadgets that are too frequent in a day or week will certainly lead to the lives of children who tend to be more concerned with their gadgets than playing outside the home. The use of gadgets with a relatively high intensity in early childhood is more than 45 minutes in one use per day and more than 3 times per day. Good use of gadgets in early childhood is no more than 30 minutes and only 1-2 times per day. The criteria for using gadgets in children aged 3-5 years are called excessive if they are used for more than one hour (WHO, 2019). For this reason, it is necessary to have discipline and boundaries that parents do when early childhood uses gadgets, because continuous use of gadgets and no time limit can have a negative impact on gadget addiction from an early age, especially children's physical and motor development.

Motor development is the development of body movement control through coordination of central nervous, peripheral and muscle activities that arise from the development of reflexes that begin at birth, the ability to move in basic motor skills describes the degree of mastery of skills in using the fingers. hand, eye-hand and eye-foot coordination, tempo balance, and visual perception (Yul et al., 2018). The level of gross motor skills carried out was significantly different from the type of area of residence and age level (Dlani et al., 2020; Suherman et al., 2020). The results of previous research, the people of East Java in carrying out physical activity have not reached the planned stage with a percentage of $63.2 \%$, it is proven that the final results of the sport have not reached the target and until 2017 the obesity rate in East Java is still high (Nurhasan et al., 2018). There are research results in the urban area of East Java which states that the level of physical motor skills is still low due to one of them that children are more likely to spend their free time playing gadgets and other activities that do not expend energy (Ermona \& Wirjatmadi, 2018). Children aged 2-7 years still need special assistance from their parents in using gadgets so that the negative impact of gadgets is avoided (Novianti \& Garzia, 2020).
This study focused on the length of use of gadgets and the level of gross motor skills of preschool-aged children, while parents only focused on the physical activities that children do at home and the total duration of their use of gadgets in their spare time. This study aims to reveal the duration of gadget use and the level of gross motor skills that are appropriate for preschool age. The importance of this research is to provide knowledge and awareness to parents regarding the importance of controlling and limiting children's use of gadgets because it has an impact on the psychomotor development of children. Fulfillment of physical skills from an early age to become a habit and minimize children's motor barriers to apply an active lifestyle that aims to improve children's physical condition, one of which is to improve gross motor skills of preschool-age children in the Urban area of East Java. The purpose of this study is to identify the duration of gadget use and the level of gross motor skills of preschoolers in the urban area of East Java.

\section{METHOD}

This research was conducted by identifying sedentary activities in front of the screen using the IPAQ questionnaire and identifying children's gross motor skills using the Test of Gross Motor Development (TGMD-3). The sample is preschool children (3-5 years) in the East Java Urban area which consists of Malang City and Kediri City. Sampling in the city of Malang amounted to 15 students, and the city of Kediri amounted to 11 students, the total sample amounted to 26 students. The sampling protocol technique that will be carried out is to apply the systematic random sampling method. To get approval from each PAUD which also includes permission from children to be involved in research activities. Permission from the PAUD institution will later go through the manager or personnel responsible for the PAUD. After coordinating with PAUD managers, it will be socialized to parents related to this research program which aims to determine the duration of gadget use in children and the level of children's gross motor skills and will be followed by filling out the consent form as a legal document for the implementation of sampling. The data analysis technique used the Bivariate analysis method, namely simple correlation using two variables.

\section{RESULTS AND DISCUSSION}

Respondents in this study amounted to 26 people, 14 men and 12 women. Here it is found that 
the mean of the analysis results: 50, Standard Deviation (SD): 10 for both male and female respondents. The minimum and maximum values of the analysis results are in the range for non-locomotor showing a range of 25.48-66.48, object control showing a range of 20.19-62, and sedentary screen time (SST) showing a range of 32.73-60.23. The population of the study has a normal distribution so that it meets the prerequisites for analysis.

The analysis carried out was bivariate analysis to determine the relationship between sedentary activities in front of the screen and the level of gross motor skills of preschoolers in the urban area of East Java. The details are explained in the table below:

Table 1. Results of Descriptive Statistical Analysis (Sedentary Activity and Gross Motor Skills)

\begin{tabular}{|c|c|c|c|c|c|c|c|}
\hline & \multirow[b]{2}{*}{$(\mathbf{N})$} & \multirow[b]{2}{*}{ Mean } & \multirow[b]{2}{*}{$\begin{array}{l}\text { Standard } \\
\text { Deviation }\end{array}$} & \multirow[b]{2}{*}{ Minimum } & \multirow[b]{2}{*}{ Maximum } & \multicolumn{2}{|c|}{$95 \% \pm \mathrm{CI}$} \\
\hline & & & & & & $\begin{array}{l}\text { Lower } \\
\text { Bound }\end{array}$ & $\begin{array}{l}\text { Upper } \\
\text { Bound }\end{array}$ \\
\hline \multicolumn{8}{|l|}{ Gross Motor Skills } \\
\hline - Non-Lokomotor & 26 & 50 & 10 & 25.48 & 66.48 & 45.9609 & 54.0391 \\
\hline - Object Control & 26 & 50 & 10 & 20.19 & 62 & 45.9609 & 54.0391 \\
\hline $\begin{array}{l}\text { Sedentary Screen } \\
\text { Time (SST) }\end{array}$ & 26 & 50 & 10 & 32.73 & 60.23 & 45.9609 & 54.0391 \\
\hline \multicolumn{8}{|c|}{ SST ( 7 days) } \\
\hline $\begin{array}{l}\text { Sedentary Screen } \\
\text { Time (SST) }\end{array}$ & 26 & 50 & 10 & 32.73 & 60.23 & 45.9609 & 54.0391 \\
\hline \multicolumn{8}{|c|}{ Correlation } \\
\hline $\begin{array}{l}\text { Gross Motor Skills } \\
\text { and Sedentary Screen } \\
\text { Time (SST) }\end{array}$ & & 26 & & & & .003 & \\
\hline
\end{tabular}

Based on table 1, it is known that the results of the Bivariate correlation show 0.003 (sig <0.05), which means that there is a relationship between sedentary activity and the level of gross motor skills of preschool-aged children in the urban area of East Java. The results of Gross Motor Skills show that the gross motor development of children aged 3-5 years in the urban area of East Java is in the poor category, however, there are still some children with good gross motor skills development. It is called a lack of criteria if the child in making movements has difficulty following, and includes good criteria if the child can follow every movement perfectly and has no difficulty in following. The categories used in the TGMD data are adjusted to the following norms: 1 ) very superior if the value is $>130 ; 2$ ) superior if the value is $121-130 ; 3)$ above average if the value is $111-120 ; 4)$ average if the value is $90-110 ; 5$ ) average bellows if the value is $80-89$; 5 ) poor if the value is $70-79$, and very poor if the value is <70. Optimal development starts at the age of 0-5 years, in developing countries, there is still a delay in gross motor development at the age of 3-5 years (49\%) there is still a delay of $8.83 \%$ (Hasanah \& Ansori Nisa, 2013). Children's physical and motor development tend to follow a relatively similar pattern so that they can be seen as normal or experiencing obstacles. However, there are differences in the rate of development between one child and another, so that no two individuals are the same, both in physical growth and motor development. Motor development depends on the maturity of muscles and nerves so that children will find it difficult to show certain skills when they are not yet mature (Ulfah \& Putra, 2021). Daily movements that can be used to improve gross motor skills in early childhood are small ball games (Nur \& Mulyana, 2017).

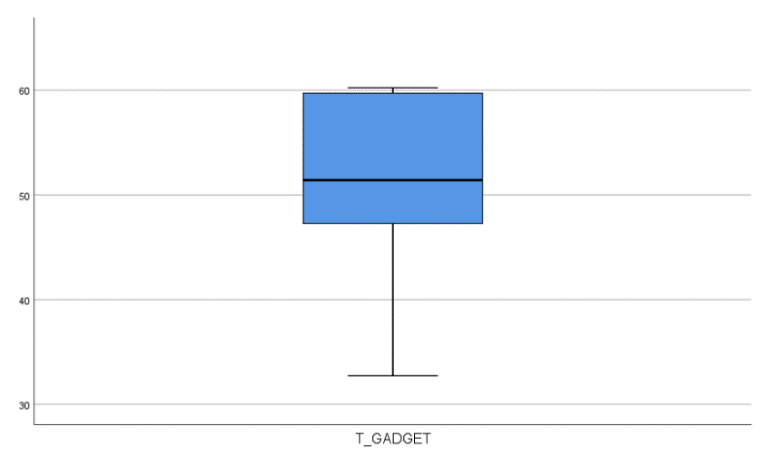

Figure 1. Sedentary Activity Capacity 
In the picture above, it is explained that the level of data distribution is in the normal category. This data represents the distribution of the population related to the level of sedentary activity in front of the screen. The results of the analysis show that the level of sedentary activity in front of the screen is in the range of 40-60 minutes per day.

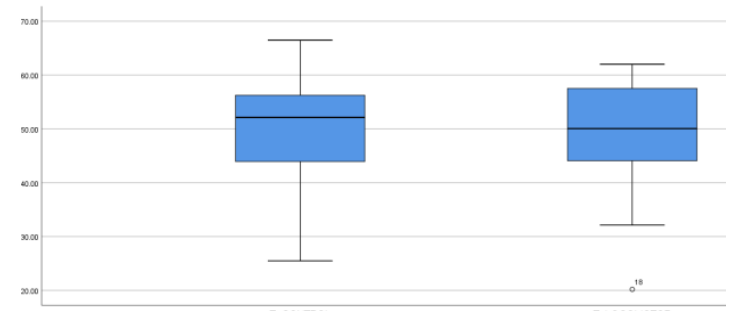

Figure 2. The Capacity of Children's Gross Motor

\section{Levels}

In the picture above, it is explained that the level of data distribution is in the normal category. This data represents the distribution of the population related to the level of gross motor movement of children consisting of Non-Locomotor and Object Control. The results of the analysis show that the level of NonLocomotor skills is in the range of 40.00-60.00 and Object Control skills are in the range of 40.00-60.00.

The purpose of this study was to identify the duration of sedentary activity in front of a screen and the level of gross motor skills of preschoolers in urban areas. Urban areas are defined as urban areas. The characteristics of urban areas are high population growth and density, the dominant economic sector is non-agriculture, and the awareness of urban residents in the area (Hapsari \& Aulia, 2019). The majority of the population in urban areas is living in residential areas. Environmental factors are one of the most influential factors in the growth and development of children. Several studies are showing that the residential environment influences physical activity patterns (Muthuri et al., 2014). Environments and schools located in urban areas have relatively small play areas, children are equipped with indoor play facilities. Preschool age is a time when children spend their time playing which involves gross motor skills.

Gross motor is a body movement that uses large muscles (Lumintuarso, 2013). Gross motor development in children trains physical movements in the form of coordinating body movements in children, such as crawling, running, tiptoeing, jumping, hanging, throwing and catching, and maintaining balance (Yul et al., 2018). Children who have good motor skills will be easier to adjust and encourage children to easily make friends with their peers when doing physical activities (Wijayanti \& Pangestu, 2018). Physical activity refers to all daily movements such as walking, cycling, sports, active recreation, and playing that can be done with any skill level (Physical Activity, n.d.). Children's physical activity is a series of movements that are adapted to the age range for the needs of children's growth and development (Burhaein, 2017). But in the current covid-19 pandemic, children prefer to spend their time playing gadgets rather than playing with their peers, this causes children to do less physical activity, because they prefer to sit in front of the screen and enjoy the world around them. in these gadgets. This situation will affect the development of children, one of which is motor development. The existence of gadgets makes children have poor motor skills (Aldimasi et al., 2018).

Technological progress in the current era of globalization is very rapid, especially the development of screen-based technology such as gadgets. Technological developments can affect the lives of children, especially preschoolers. At the preschool age where the phase of growth and development of children takes place rapidly. Children prefer to play with gadgets than playing with their friends. Children are busy playing with gadgets for hours without any physical activity being done (Khaironi, 2018). This of course results in children having a lazy behavior to move (sedentary behavior). The use of screen-based technology and its interaction with children will result in reduced movement activities. Children who experience more sedentary behavior will spend their time playing alone, moving less and interacting with the outside environment. This of course will also affect the behavior of children both individually and to other people and the environment. Children will tend to be more emotional, aggressive, less independent, difficult to get along and communicate with other friends (Bingham et al., 2016; Cliff et al., 2016; Hinkley et al., 2014; Teychenne et al., 2015).

The results of this study indicate that most children in the urban area of East Java have a duration of sedentary activity in front of the screen with a span of more than 1 hour per day. The use of gadgets with a long duration in children causes children to be lazy to move and do activities. They prefer to sit in front of the gadget and enjoy the games that have certain features compared to 
interacting with their peers in the real world. This certainly has a negative impact on the development and health of children, especially in terms of the brain and psychology. The criteria for using gadgets in children aged 3-5 years are called excessive if they are used for more than one hour (WHO, 2019). It is not uncommon for children to have difficulty concentrating because the child's brain has been dispersed in an unreal world (Sonia, 2013).

The results of the correlation between the duration of gadget use and the level of gross motor skills have a fairly strong relationship, there is a relationship between the duration of gadget use and the level of gross motor skills. For children who use gadgets with a high frequency, the level of gross motor skills shows poor results, and conversely for children who use gadgets with a normal frequency, the level of gross motor skills shows good results.

Gadgets are an interesting thing for them, especially with the presence of online game applications found on gadgets, so most of them spend all day playing gadgets. They become no longer interested in playing with their peers because they are more interested in digital games (Ameliola \& Nugraha, 2015). This age should be used by children to interact socially with their peers as the formation of children's character according to their age level. The existence of gadgets in this rapidly growing era has both positive and negative impacts on users, both children, and adults. Even ironically, gadgets are not foreign goods for preschoolers (3-5 years) who are not yet worthy of using gadgets (Imron, 2018). One of the factors that play an important role in giving the impact of gadgets is the duration of their use. According to research conducted by Rideout (2013), the results showed that there were children aged 2-4 years who spent their time playing gadgets for 1 hour 58 minutes per day and children aged 5-8 years spent playing for 2 hours 21 minutes every day. day. Many factors cause children to become addicted to playing gadgets, most of which start from a form of diversion or lack of time from parents to accompany children to play. Based on the results of the study, it shows that parents let their children play with gadgets without giving time limits and without supervision, and parents also cannot accompany their children to interact or play together.

\section{CONCLUSIONS}

Based on the results of the study, it can be concluded that there is a significant relationship between the duration of sedentary activity in front of the screen and the level of gross motor skills of preschool-aged children in the Urban area of East Java because the Bivariate correlation value obtained shows 0.003 ( $\mathrm{sig}<0.05$ ). More than half of preschoolage children in the Uban area of East Java are highfrequency gadget users. Excessive use of gadgets from normal limits will greatly affect children's development, especially physical and gross motor development.

Efforts or interventions that must be done that the use of gadgets in children must be considered include not giving too many opportunities for children to play with their gadgets, because scientifically if too often it will cause things that are not good for future development, it is not wrong if children are introduced to gadgets, However, as parents, whether they want to be aware of it or not, they are required to be smart parents who must be careful in giving things to children such as gadgets so that from this technology parents can reduce their negative effects and can add insight and intelligence to children or become a tool to strengthen the relationship between their parents. children and parents. In addition, there need to be disciplinary rules at home that are notified to children and parents of students that it is important to give the duration of playing gadgets so that the frequency with which children use gadgets can be reduced, for example in a week they are only allowed to use gadgets twice or children are not allowed to use them every day.

\section{REFERENCES}

Aldimasi, H. H., Miqdady, A. M., Elsori, D., \& Nazir, A. (2018). Impact of Gadgets on Children' $s$ Development. 5(2), 1-7.

Ameliola, S., \& Nugraha, H. D. (2015). Perkembangan Media Informasi Dan Teknologi Terhadap Anak Dalam Era Globalisasi. Perkembangan Media Informasidan Teknologi Terhadap Perkembangan Anak, 2, 400.

Bingham, D. D., Costa, S., Hinkley, T., Shire, K. A., Clemes, S. A., \& Barber, S. E. (2016). Physical Activity During the Early Years: A Systematic Review of Correlates and Determinants. American Journal of Preventive Medicine, 51(3), 384-402. https://doi.org/10.1016/j.amepre.2016.04.022

Burhaein, E. (2017). Aktivitas Fisik Olahraga untuk Pertumbuhan dan Perkembangan Siswa SD. Indonesian Journal of Primary Education, 1(1), 51. https://doi.org/10.17509/ijpe.v1i1.7497

Cliff, D. P., Hesketh, K. D., Vella, S. A., Hinkley, T., Tsiros, M. D., Ridgers, N. D., Carver, A., Veitch, J., Parrish, A. M., Hardy, L. L., 
Plotnikoff, R. C., Okely, A. D., Salmon, J., \& Lubans, D. R. (2016). Objectively measured sedentary behaviour and health and development in children and adolescents: Systematic review and meta-analysis. Obesity Reviews, 17(4), 330-344. https://doi.org/10.1111/obr.12371

Dlani, D. T. R., Kurniawan, A. W., Yudasmara, D. S., Hariadi, I., Taufik, \& Fadhli, N. R. (2020). Time Patterns of Physical Activity for 1st Grade to 6th Grade Students Living in the Lowland Area. 29(Icssh 2019), 26-31. https://doi.org/10.2991/ahsr.k.201107.007

Dwi Murdaningsih, \& Mansyur Faqih. (2014). Survei: Jutaan Anak Usia SD Kecanduan "Gadget" | Republika Online. https://www.republika.co.id/berita/trendtek/gad get/14/01/17/mzjj2x-survei-jutaan-anak-usiasd-kecanduan-gadget

Elfiadi. (2018). DAMPAK GADGET TERHADAP PERKEMBANGAN. 9(2), 97-110.

Ermona, N. D. N., \& Wirjatmadi, B. (2018). Hubungan Aktivitas Fisik Dan Asupan Gizi Dengan Status Gizi Lebih Pada Anak Usia Sekolah Dasar Di Sdn Ketabang 1 Kota Surabaya Tahun 2017 Relationship between Physical Activity, Nutrition Intake and Overweight Status among Elementary School Student in SD. 97-105. https://doi.org/10.20473/amnt.v2.i1.2018.97105

Hapsari, A. D., \& Aulia, B. U. (2019). Tipologi Wilayah Peri Urban Kabupaten Sidoarjo Berdasarkan Aspek Fisik, Sosial, dan Ekonomi. Jurnal Teknik ITS, 7(2). https://doi.org/10.12962/j23373539.v7i2.34248

Hasanah, N., \& Ansori Nisa, M. (2013). HUBUNGAN TINGKAT PENGETAHUAN IBU DENGAN PERKEMBANGAN MOTORIK KASAR ANAK USIA ( 3 - 5 TH ). 60-66.

Hinkley, T., Teychenne, M., Downing, K. L., Ball, K., Salmon, J., \& Hesketh, K. D. (2014). Early childhood physical activity, sedentary behaviors and psychosocial well-being: A systematic review. Preventive Medicine, 62, 182-192. https://doi.org/10.1016/j.ypmed.2014.02.007

Imron, R. (2018). Hubungan Penggunaan Gadget dengan Perkembangan Sosial dan Emosional Anak Prasekolah di Kabupaten Lampung Selatan. Jurnal Ilmiah Keperawatan Sai Betik, 13(2),

148. https://doi.org/10.26630/jkep.v13i2.922

Khaironi, M. (2018). Perkembangan Anak Usia Dini.
3(1), 1-12.

Lumintuarso, R. (2013). Pembinaan Multilateral Bagi Atlet Pemula. UNY Press.

Mashrah, H. (2018). The Impact of Adopting and Using Technology by Children Hind Talal Mashrah . ( 2017 ). The Impact of Adopting and Using Technology by The Impact of Adopting and Using Technology by Children. October. https://doi.org/10.11591/edulearn.v11i1.5588

Muthuri, S. K., Wachira, L. J. M., Leblanc, A. G., Francis, C. E., Sampson, M., Onywera, V. O., \& Tremblay, M. S. (2014). Temporal trends and correlates of physical activity, sedentary behaviour, and physical fitness among schoolaged children in Sub-Saharan Africa: A systematic review. In International Journal of Environmental Research and Public Health (Vol. 11, Issue 3). https://doi.org/10.3390/ijerph110303327

Novianti, R., \& Garzia, M. (2020). Jurnal Obsesi : Jurnal Pendidikan Anak Usia Dini Penggunaan Gadget pada Anak Usia Dini ; Tantangan Baru Orang Tua Milenial Abstrak. 4(2), 1000-1010. https://doi.org/10.31004/obsesi.v4i2.490

Nur, L., \& Mulyana, E. H. (2017). PERMAINAN BOLA KECIL UNTUK MENINGKATKAN KELOMPOK B DI TK PERTIWI DWP KOTA TASIKMALAYA. 1(1), 53-65.

Nurhasan, Pramono Agung, B., \& Hijrin, F. (2018). IDENTIFIKASI KEBIASAAN MASYARAKAT JAWA TIMUR DALAM Mempertahankan kinerja tubuh dalam jangka waktu yang lama adalah sebuah goal setting yang diingkan setiap orang setiap hari. Dengan kondisi tubuh yang optimal maka seseorang akan mampu mempertahankan kua. 1-6.

Physical activity. (n.d.). Retrieved October 17, 2021, from https://www.who.int/healthtopics/physical-activity\#tab=tab_1

Sonia, A. (2013). PERKEMBANGAN MEDIA INFORMASI DAN TEKNOLOGI TERHADAP ANAK DALAM ERA GLOBALISASI.

Suherman, A., Jajat, Rahayu, N. I., Sultoni, K., Risma, R., \& Agust, K. (2020). Early Childhood Physical Activity and Sedentary Behavior in Indonesia: Objectively Measure Using Accelerometer. 21(Icsshpe 2019), 426428. https://doi.org/10.2991/ahsr.k.200214.114

Teychenne, M., Costigan, S. A., \& Parker, K. (2015). The association between sedentary behaviour and risk of anxiety: A systematic review Health behavior, health promotion and society. $B M C$ Public Health,

15(1). 
https://doi.org/10.1186/s12889-015-1843-X

Ulfah, A. A., \& Putra, A. J. A. (2021). Analisis Penerapan Senam Irama dalam Meningkatkan Kemampuan Motorik Kasar Anak Usia Dini. $5(2)$, 1844-1852. https://doi.org/10.31004/obsesi.v5i2.993

WHO. (2019). GUIDELINES ON PHYSICAL ACTIVITY , SEDENTARY BEHAVIOUR.

Wijayanti, K., \& Pangestu, L. B. (2018).
Perkembangan Motorik Kasar Anak Usia Pra Sekolah Gross Motor Development Of Preschools Children. 145-151.

Yul, S., Poernomo, D. I. S. H., \& Mahanani, S. (2018). PERKEMBANGAN MOTORIK ANAK USIA PRASEKOLAH DI POSYANDU BALITA MAWAR DAN KENANGA. 4(2). 